DOI: $10.19195 / 0524-4544.327 .23$

\author{
PAWEŁ BORSZOWSKI \\ ORCID: 0000-0003-3570-2101 \\ Uniwersytet Wrocławski \\ pawel.borszowski@uwr.edu.pl
}

\title{
Definiowanie pojęć w prawie podatkowym a ustalenie nowego (innego) znaczenia danego określenia
}

\begin{abstract}
Abstrakt: W artykule poddano analizie jedną z podstaw definiowania pojęć w prawie podatkowym - ustalenie nowego znaczenia terminu. Autor wskazuje, że ustawodawca podatkowy, formułując definicje legalne oparte na wskazaniu nowego znaczenia, nie korzysta z determinantów. $\mathrm{W}$ artykule wskazano determinanty pierwszego i drugiego stopnia dla formułowania tych definicji.
\end{abstract}

Słowa kluczowe: definicje legalne w prawie podatkowym, determinanty tworzenia definicji legalnych, nowe znaczenie terminu.

\section{Wprowadzenie}

Rozpatrywanie prawa podatkowego z uwzględnieniem relacji pomiędzy obrotem gospodarczym a konkretnymi rozwiązaniami normatywnymi tego prawa może dotyczyć także użycia odpowiednich środków techniki prawodawczej. Analiza regulacji zarówno ogólnego, jak i szczegółowego prawa podatkowego prowadzi do wniosku, że ustawodawca podatkowy nie tylko nie zawsze dostrzega konieczność uwzględnienia tej relacji, ale także nie zawsze dokonuje wyboru właściwych środków techniki prawodawczej dla tego zadania. Można wskazać dwa charakterystyczne sposoby wyrażenia owej relacji, tj. z jednej strony poprzez użycie środków techniki prawodawczej zapewniających elastyczność przepisów prawa podatkowego, a z drugiej strony definicje legalne. Wydaje się, iż rozpatrywanie tych dwóch sposobów wyrazu normatywnego jako odrębnych, ale także 
poprzez istniejące powiązania ${ }^{1}$, może stać się jednym z ważnych zadań nie tylko doktryny, ale także praktyki podatkowej. Zwłaszcza dla ustawodawcy podatkowego powinno stać się istotną wskazówką do poprawy między innymi sposobu ujmowania zakresu regulacji, ale także poziomu jej szczegółowości normatywnej. Poziom szczegółowości normatywnej regulacji prawa podatkowego stanowi jeden $\mathrm{z}$ istotnych problemów dla ustawodawcy podatkowego. Głównie przy analizie zakresu przedmiotowego opodatkowania ${ }^{2}$.

Ustawodawca podatkowy, mając na względzie konieczność odzwierciedlenia relacji pomiędzy obrotem gospodarczym a prawem podatkowym, stosunkowo często korzysta $\mathrm{z}$ definicji legalnych. Korzystanie z tego typu rozwiązań normatywnych jest niewątpliwie dobrym zabiegiem $\mathrm{z}$ uwagi na zasadę pewności prawa podatkowego, a zatem wpisuje się bezpośrednio w postulat realizacji wartości wewnętrznych systemu prawa odniesionych do prawa podatkowego. Nie można jednakże postawić znaku równości pomiędzy realizacją zasady pewności prawa podatkowego a stosowaniem definicji legalnych. W każdym przypadku bowiem określenia i umieszczenia definicji legalnej w prawie podatkowym należy jednocześnie oceniać konsekwencje jej wprowadzenia nie tylko dla prawa podatkowego, ale także dla całego systemu prawa. Skutkiem bowiem sformułowania definicji legalnej jest zakreślenie pewnego obszaru normatywnego i wskazanie na jednolity sposób jego rozumienia. Idealnym rozwiązaniem byłoby, gdyby wprowadzona definicja legalna była stosowana w praktyce w taki sposób, jaki zamierzył normodawca. Niestety nie zawsze jest to realizowane. Przy czym nie tylko z powodu odejścia od zakresu definicji danego terminu w praktyce podatkowej, ale także w konsekwencji używania określeń nieostrych w jej ramach. Zatem posługiwanie się w definicji określeniami nieostrymi dla praktyki podatkowej może powodować trudności w odkodowaniu zakresu precyzowanego pojęcia.

Dla ustawodawcy podatkowego problemem jest nie tylko formułowanie definicji legalnych jako ograniczenie obszaru nieostrości ${ }^{3}$ zgodnie z pewnym wzorem określonym w rozporządzeniu w sprawie „Zasad techniki prawodawczej”4 . Chodzi o ujmowanie tej definicji jako ograniczenie obszaru nieostrości, ale jednocześnie próbę odzwierciedlenia relacji pomiędzy obrotem gospodarczym a prawem podatkowym.

1 Zob. P. Borszowski, Pomiędzy elastycznościa przepisów prawa podatkowego a definicjami legalnymi, [w:] Księga jubileuszowa ku czci profesor Krystyny Sawickiej: gromadzenie i wydatkowanie środków publicznych: zagadnienia finansowoprawne, red. W. Miemiec, Wrocław 2017.

${ }^{2}$ Zob. P. Borszowski, Określenia nieostre w przepisach dot. przedmiotu opodatkowania podatkiem dochodowym od osób fizycznych (wprowadzenie do problematyki), „BAS” 2018, nr 2.

3 W kwestii sposobów ograniczenia nieostrości zob. M. Zieliński, [w:] S. Wronkowska, M. Zieliński, Komentarz do zasad techniki prawodawczej, Warszawa 2012, s. 283.

$4 \S 146$ ust. 1 pkt 2 Rozporządzenia Prezesa Rady Ministrów w sprawie „Zasad techniki prawodawczej” z dnia 20 czerwca 2002 r. (tekst jedn. Dz.U. z 2016 r. poz. 283). 
W przepisach prawa podatkowego dość charakterystyczna staje się sytuacja formułowania definicji legalnych $w$ takim kształcie normatywnym, w jakim nadaje się nowe znaczenie danego określenia. Niewątpliwie w rozporządzeniu w sprawie „Zasad techniki prawodawczej” wprowadzono odpowiednią wskazówkę co do formułowania takich definicji ${ }^{5}$. $\mathrm{Z}$ uwagi jednakże na istotę prawa podatkowego, a także sposób regulacji z wykorzystaniem administracyjnoprawnej metody, formułowanie definicji legalnych $\mathrm{w}$ oparciu o wyrażoną w tym rozporządzeniu potrzebę ustalenia nowego (innego) znaczenia danego określenia wymaga ostrożności. Specyficzny charakter norm prawa podatkowego, akcentowana w doktrynie autonomia ustawodawcy podatkowego ${ }^{6}$, nie powinny być uzasadnieniem dla dowolnego korzystania przez ustawodawcę z tych definicji, skoro w systemie prawa funkcjonują definicje określonych pojęć.

$\mathrm{W}$ związku z tym teza przyjęta $\mathrm{w}$ niniejszym artykule sprowadza się w rezultacie do stwierdzenia, że ustawodawca podatkowy powinien korzystać z determinantów przy wprowadzaniu definicji legalnych opartych na wskazaniu nowego znaczenia, a także innego znaczenia definiowanego pojęcia.

Celem niniejszego opracowania jest więc wskazanie uzasadnienia dla rozpatrywania determinantów, jakimi powinien kierować się prawodawca, podejmując decyzję o formułowaniu definicji legalnej, w takim przypadku w prawie podatkowym, a następnie określenie tych determinantów. Ustawodawca podatkowy nie zawsze bowiem dostrzega te determinanty, co można zauważyć, analizując definicję działalności gospodarczej wprowadzoną w przepisach prawa podatkowego.

\section{Determinanty w obszarze potrzeby ustalenia nowego znaczenia danego określenia (determinanty pierwszego stopnia)}

Badanie determinantów wprowadzenia definicji legalnych w ramach potrzeby ustalenia nowego znaczenia danego określenia należy poprzedzić uzasadnieniem dla ich rozpatrywania. Przy czym chodzi o umownie nazwane determinanty pierwszego stopnia. Nazwa ta jest konsekwencją uznania za wyjściowe rozwiązania zaproponowanego w $\S 146$ ust. 1 pkt 4 rozporządzenia w sprawie „Zasad techniki prawodawczej" w odróżnieniu od rozwiązania zaproponowanego w $\S 148$ tego rozporządzenia, w którym można poszukiwać uzasadnienia, a także determinantów drugiego stopnia.

5 W $§ 146$ ust. 1 pkt 4.

6 Szerzej w kwestii autonomii ustawodawcy podatkowego i jej pewnych ograniczeń zob. R. Mastalski, Autonomia prawa podatkowego a spójność i zupetność systemu prawa, „Przegląd podatkowy" 2003, nr 10. 
Uzasadnienie dla poszukiwania tych determinantów wynika po pierwsze $\mathrm{z}$ umiejscowienia tego rozwiązania w całości $\S 146$ ust. 1 rozporządzenia, po drugie ze szczególnej roli tej propozycji normatywnej. Chodzi bowiem o ustalenie nowego znaczenia danego określenia, a zatem pojawia się zagadnienie nowości znaczeniowej danego wyrażenia.

Samego umiejscowienia tego rozwiązania w rozporządzeniu w sprawie „Zasad techniki prawodawczej” nie należy kwalifikować jako wskazania bezpośredniego determinantu posługiwania się tymi środkami techniki prawodawczej $\mathrm{w}$ prawie podatkowym. Inaczej mówiąc, nie powinno się tego rozumieć w taki sposób, że korzystanie z definicji legalnych w prawie podatkowym z założeniem nowości znaczeniowej ${ }^{7}$ może następować zupełnie wyjątkowo po wykorzystaniu wszystkich dostępnych determinantów, które możemy ustalić w oparciu o analizę podstaw formułowania definicji w oparciu o $\S 146$ ust. 1 pkt 1-3 rozporządzenia. Zaproponowane rozwiązania, także z odniesieniem do prawa podatkowego, są rozłączne w tym znaczeniu, że można je zastosować niezależnie od siebie. Nie wyłącza to także sytuacji, w której w danym przypadku formułowania definicji w prawie podatkowym ustawodawca będzie korzystał jednocześnie z determinantów umiejscowionych w obszarze więcej niż jednej podstawy formułowania definicji.

Niemniej jednak takie umiejscowienie proponowanego rozwiązania powinno być istotną wskazówką dla normodawcy, aby nadawanie nowego znaczenia analizowanego określenia w prawie podatkowym nie stało się regułą. Można zatem przyjąć, że umiejscowienie tego rozwiązania jest pośrednim determinantem częstotliwości korzystania z tego typu definicji legalnych.

Kolejne determinanty pierwszego stopnia należy ustalać w obszarze sformułowania przyjętego w $\S 146$ ust. 1 pkt 4 rozporządzenia w sprawie „Zasad techniki prawodawczej" $\mathrm{z}$ ich odniesieniem do prawa podatkowego. Dają one podstawę do przyjęcia dwóch z nich, tj. po pierwsze determinantów dziedziny regulowanych spraw, a po drugie determinantów potrzeby ustalenia nowego znaczenia danego określenia. Muszą one zaistnieć łącznie, aby można było posiłkować się definicjami legalnymi o takim kształcie normatywnym, jaki wprowadza nowe znaczenie danego określenia. Jednakże dla celów analizy statycznej wskazano na te dwa determinanty, które w ujęciu funkcjonalnym są spełnione łącznie.

Jeżeli chodzi o determinant dziedziny regulowanych spraw, należy uznać, że niewątpliwie tą dziedziną będzie obszar prawa podatkowego jako podstawa do analizowania spraw podatkowych. Przy czym, z uwagi na założenia przyjęte w początkowej części tego artykułu, w ramach tego determinantu należy uwzględniać relację pomiędzy obrotem gospodarczym a prawem podatkowym. W doktrynie przyjęto pogląd, że relacja ta ma wymiar pewnego opóźniania się regulacji prawa

7 Pod pojęciem nowości znaczeniowej należy rozumieć sytuację nadawania nowego znaczenia danemu określeniu ze względu na dziedzinę regulowanych spraw. 
podatkowego w stosunku do obrotu gospodarczego ${ }^{8}$. Przy czym zasadniczym założeniem jest to, aby regulacje prawa podatkowego nie wyprzedzały rozwiązań normatywnych obrotu gospodarczego. Podejmując zatem decyzję o wdrożeniu definicji o tym kształcie normatywnym, należy jednocześnie mieć na uwadze, aby poprzez jej wprowadzenie oraz nadanie normatywnego wyrazu nie doprowadzić do zniekształcenia wskazanej relacji pomiędzy obrotem gospodarczym (regulacjami tego obrotu) a prawem podatkowym.

W przypadku drugiego ze wskazanych determinantów warto w pierwszej kolejności zbadać, czy de facto jest on wyznaczony poprzez potrzebę ustalenia nowego znaczenia danego określenia. Termin potrzeba jest bowiem określeniem nieostrym, a skutkiem jego zastosowania jest przeniesienie nieostrości na cały zwrot, a zatem także na rozpatrywany determinant. Należy ponadto zauważyć, że chodzi o potrzebę ustalenia nowego znaczenia danego określenia, a zatem potrzebę wprowadzenia de facto nowości znaczeniowej w stosunku do już funkcjonującego znaczenia danego określenia. Wprowadzenie nowości znaczeniowej danego określenia jako konsekwencji definicji legalnej nie powinno być oceniane wyłącznie w kontekście potrzeby. Może to bowiem doprowadzić do instrumentalnego podejścia nie tylko co do wyboru obszaru znaczeniowego dla jego zdefiniowania, ale także co do kształtu normatywnego dla tej definicji. Termin potrzeba wiąże się ze zbyt dużym obszarem swobody wyboru danego wariantu działania, co nie odpowiada nie tylko administracyjnoprawnej metodzie regulacji, ale także charakterowi norm prawa podatkowego. Ponadto może wywołać negatywne skutki dla całego systemu prawa, w którym funkcjonują już zdefiniowane dane terminy o innym zakresie znaczeniowym.

Determinant potrzeby ustalenia nowego znaczenia danego określenia należy „wyostrzyć” w obszarze prawa podatkowego. Inaczej mówiąc, jego zakres należy ograniczyć w sensie zmniejszenia swobody wyboru nowości znaczeniowej danego określenia.

Wydaje się, że taki skutek można uzyskać poprzez wprowadzenie determinantu konieczności zapewnienia nowości znaczeniowej danego określenia. Nie oznacza to zanegowania rozwiązania, które przyjęte zostało w rozporządzeniu w sprawie „Zasad techniki prawodawczej”. Można bowiem uznać, że determinant potrzeby ustalenia nowego znaczenia danego określenia ma wymiar uniwersalny w tym sensie, że twórcy tego rozporządzenia, poprzez takie jego ukształtowanie, starali się zapewnić jego zastosowanie do każdej gałęzi prawa niezależnie od metody regulacji. Sformułowanie o potrzebie ustalenia nowego znaczenia danego określenia można $\mathrm{w}$ związku $\mathrm{z}$ tym oceniać jako determinant o pewnym stopniu elastyczności, przy czym jedynie w sensie dopasowania do specyfiki danej gałęzi prawa z właściwą jej metodą regulacji. Chodziło wobec tego o nieograniczanie

8 P. Borszowski, Określenia nieostre i klauzule generalne w prawie podatkowym, Warszawa 2017. 
niejako na wejściu jego zastosowania. Natomiast nie powinno się „przenosić” tak sformułowanego determinantu w obszar każdej gałęzi prawa, w szczególności prawa podatkowego.

W ramach prawa podatkowego determinant ten powinien uzyskać kształt normatywny w sensie konieczności zapewnienia nowego znaczenia danego określenia. Wprowadzenie determinantu konieczności zapewnienia nowego znaczenia danego określenia ze względu na dziedzinę regulowanych spraw, a tym samym $\mathrm{z}$ uwagi na regulacje prawa podatkowego, nie stanowi zatem zniekształcenia tego sformułowania, które przyjęto w rozporządzeniu w sprawie "Zasad techniki prawodawczej”. Dla ustawodawcy podatkowego powinno to stanowić istotną wskazówkę co do posługiwania się takowymi definicjami. Oznacza to dla prawodawcy po pierwsze powinność uwzględniania istniejącej konieczności ustalenia nowego znaczenia danego określenia, a nie jedynie potencjalnej czy przewidywanej. Wymaga to zatem wnikliwego badania zarówno projektowanego obszaru regulacji prawa podatkowego ujętej w formie definicji legalnej, jak i jej skutków w relacji do istniejących już definicji danego terminu. Chodzi o moment poprzedzający podjęcie decyzji co do wprowadzenia definicji danego pojęcia w prawie podatkowym. Na tym etapie ustawodawca podatkowy powinien mieć pewność, a nie przewidywanie, co do konieczności ustalenia nowego znaczenia danego terminu. Wpisuje się to bowiem w rolę definicji legalnej i wprowadzonego zakresu normatywnego jej odpowiadającego.

Badany determinant powinien być istotną wskazówką dla ustawodawcy podatkowego co do akcentowanej już nowości znaczeniowej. Chodzi tutaj o jej badanie na etapie poprzedzającym podjęcie decyzji co do wdrożenia takowej definicji, jak również jej sformułowania. Ustawodawca podatkowy powinien zatem unikać takich sytuacji, w których ocena nowości znaczeniowej byłaby możliwa dopiero po podjęciu decyzji co do wprowadzenia odpowiedniej definicji legalnej jako konsekwencja jej sformułowania. „Przerzucenie” tego na etap sformułowania decyzji jest niezgodne nie tylko z podnoszoną już istniejącą koniecznością, ale także z umiejscowieniem analizowanej podstawy formułowania definicji legalnych w kształcie $\S 146$ ust. 1 rozporządzenia w sprawie „Zasad techniki prawodawczej”.

Badanie to na etapie poprzedzającym podjęcie decyzji co do wprowadzenia definicji legalnej o takim kształcie normatywnym powinno odbywać się poprzez analizę funkcjonujących już tego typu rozwiązań i jednoznaczne stwierdzenie konieczności zdefiniowania danego terminu, nadając mu nowe znaczenie. Taka decyzja powinna być poprzedzona wnikliwym badaniem możliwości zastosowania danej definicji legalnej funkcjonującej już w systemie prawa w istniejącym kształcie normatywnym.

Kolejny problem, jaki powinien dostrzegać ustawodawca podatkowy, to ocena nowości znaczeniowej w sensie jej stopnia. Przyjęcie bowiem determinantu wyznaczonego jako konieczność, a nie potrzeba ustalenia nowego znaczenia danego określenia nie oznacza, że tylko w przypadku wysokiego stopnia nowości znacze- 
niowej istnieje dla ustawodawcy podatkowego podstawa do wprowadzenia takiej definicji. Ocena stopnia nowości znaczeniowej wydaje się być trudnym zabiegiem dla ustawodawcy podatkowego. $Z$ jednej strony należy bowiem unikać sytuacji, w których normodawca będzie wprowadzał definicję legalną w każdym przypadku, gdy zachodzi wątpliwość co do tego, czy skutkiem jej wprowadzenia jest zaistnienie stanu nowości znaczeniowej. $Z$ drugiej zaś strony nie można poprzestać na takich przypadkach, gdy jedynie zmiana całego zakresu precyzowanego pojęcia będzie uzasadniała jego nowe zdefiniowanie. Znalezienie w tym przypadku przez ustawodawcę podatkowego złotego środka jest kluczowym zadaniem dla posługiwania się tego typu definicjami. Ocena nowości znaczeniowej dotyczy zarówno etapu poprzedzającego podjęcie decyzji o wdrożeniu danej definicji, jak i samego jej sformułowania. Badając etap podejmowania decyzji, można przyjąć, że zaistnienie nowości znaczeniowej nawet dla jednego z elementów projektowanej definicji w stosunku do już istniejącej w systemie prawa będzie stanowiło podstawę do jej wprowadzenia, a jednocześnie będzie stanowiło o realizacji wskazanego determinantu. Wymaga to wnikliwej oceny każdego z elementów istniejącej w systemie prawnym definicji w porównaniu do tej projektowanej w oparciu o nowość znaczeniową.

\section{Determinanty w obszarze potrzeby ustalenia innego znaczenia danego określenia (determinanty drugiego stopnia)}

Jak już wskazano, kształt rozwiązań przyjętych w rozporządzeniu w sprawie „Zasad techniki prawodawczej” pozwala również wskazać na determinanty wprowadzenia definicji legalnych w analizowanym obszarze, które można określić jako determinanty drugiego stopnia. Nazwa ta może być użyta wobec tych determinantów, które można ustalić przy analizie § 148 tego rozporządzenia i jego recypowaniu do unormowań przyjętych w prawie podatkowym. Sformułowanie to jest umowne i używane dla odróżnienia od tych, które kwalifikowano jako pierwszego stopnia. Przy czym stopniowanie tych determinantów nie oznacza ich powiązania $\mathrm{w}$ takim sensie, że zastosowanie tych oznaczonych jako drugiego stopnia następuje dopiero po użyciu determinantów pierwszego stopnia. Chodzi bowiem o pewną sytuację szczególną, która jest konsekwencją odejścia od znaczenia nadanego definiowanemu terminowi w ustawie określanej jako „kodeks” lub „prawo”, lub innej ustawie podstawowej dla danej dziedziny spraw.

Podobnie w tym przypadku można wskazać szczególną rolę wspomnianych rozwiązań, a jako uzasadnienie ich wyróżnienia umiejscowienie po § 146 rozporządzenia w sprawie „Zasad techniki prawodawczej”. Przy czym umieszczenie 
rozwiązań w $\S 148$ tego rozporządzenia, recypowanych w obszar prawa podatkowego, stanowi także potwierdzenie zasadności ich kwalifikacji jako drugiego stopnia.

Determinanty drugiego stopnia dotyczą formułowania definicji legalnych w prawie podatkowym wyłącznie w aktach normatywnych rangi ustawy i jedynie wówczas, gdy zachodzi wyjątkowo potrzeba odstąpienia od znaczenia danego określenia ustalonego w ustawie określanej jako „kodeks” lub „prawo”, lub innej ustawie podstawowej dla danej dziedziny spraw. To wyrażenie można określić jako determinant drugiego stopnia wprowadzenia definicji legalnych, jako taki więc, który powinien być brany pod uwagę przez ustawodawcę podatkowego w przypadku, gdy decyduje się na umieszczenie definicji legalnej, odchodząc tym samym od znaczenia nadanego definiowanemu pojęciu w kodeksie czy też innej ustawie o szczególnym charakterze normatywnym, jak choćby ustawie określanej jako prawo. Sytuację taką można oceniać chociażby w kontekście definicji działalności gospodarczej formułowanej w przepisach prawa podatkowego.

Ponadto, recypując rozwiązanie przyjęte $\S 148$ rozporządzenia w sprawie „Zasad techniki prawodawczej”, można wskazać determinant drugiego stopnia sposobu formułowania definicji legalnej w prawie podatkowym. Chodzi o wyraźne podanie innego znaczenia tego określenia i zakres jego odniesienia, używając zwrotów podanych we wskazanym rozwiązaniu normatywnym.

Jeżeli zatem idzie o determinant drugiego stopnia wprowadzenia definicji legalnej wypada stwierdzić, podobnie jak miało to miejsce przy analizie w punkcie drugim niniejszego opracowania, że chodzi o jego uwzględnienie już na etapie podjęcia samej decyzji o wprowadzeniu tego środka techniki prawodawczej, mimo że istnieje definicja umieszczona $\mathrm{w}$ akcie normatywnym o szczególnym charakterze, jak choćby mającym rangę kodeksu. Determinant ten wyraża się w pierwszej kolejności poprzez sformułowanie ,zachodzi wyjątkowo potrzeba odstąpienia od znaczenia danego określenia”. Chodzi o znaczenie nadane temu określeniu w akcie normatywnym o szczególnym charakterze prawnym. Podobnie jak przy determinantach pierwszego stopnia można przyjąć, że należy akcentować stan istniejący, a nie potencjalny, gdy zachodzi już wyjątkowo potrzeba odejścia od znaczenia danego określenia. Przy czym wydaje się, że także w tym przypadku w obszarze prawa podatkowego zasadne będzie wyostrzenie kryterium potrzeby poprzez jego zastąpienie kryterium konieczności. Bowiem mimo użycia sformułowania odnoszącego się do wyjątkowości potrzeby, z uwagi na specyfikę prawa podatkowego i konsekwencje w systemie prawnym, lepszy rezultat odejścia od funkcjonującej definicji może uzyskać ustawodawca podatkowy poprzestający na determinancie wyznaczonym kryterium konieczności. Biorąc pod uwagę dodanie wyrażenia wskazującego na wyjątkowość i jego recypowanie w obszarze prawa podatkowego jako wyjątkowa konieczność, zakres tego determinantu będzie węższy w porównaniu do odpowiedniego determinantu pierwszego stopnia. Ponadto istotne znaczenie dla tego determinantu będzie miała ta część rozwiązania przy- 
jętego w § 148 rozporządzenia w sprawie „Zasad techniki prawodawczej”, w której wskazuje się na odejście od znaczenia danego określenia nadanego $\mathrm{w}$ akcie prawnym o szczególnym charakterze normatywnym. W ramach bowiem determinantów pierwszego stopnia wskazywano na nowość normatywną, z kolei w tym przypadku nie pojawia się zagadnienie nowości normatywnej, lecz odstąpienie od przyjętego już i funkcjonującego znaczenia. Wydaje się, że recypowanie tego rozwiązania w obszar prawa podatkowego nie powinno zamykać możliwości analizowania przypadków, w których mimo przyjętych definicji legalnych w kodeksie czy ustawie określanej jako prawo może zachodzić wyjątkowa konieczność nadania nowego znaczenia danego zdefiniowanego terminu. Nie ulega wątpliwości, że ranga przykładowo regulacji kodeksowej jest znacząca, jednakże nie może jednocześnie powodować braku możliwości rozpatrywania takich przypadków, w których wprowadzenie definicji legalnej będzie motywowane nowością znaczeniową, co może być uzasadnione choćby wskazywaną już w początkowej części niniejszego opracowania relacją pomiędzy obrotem gospodarczym a prawem podatkowym. Niemniej jednak punktem wyjścia będzie stwierdzenie wyjątkowej konieczności wprowadzenia takiej definicji w ustawie podatkowej.

Istotne znaczenie dla ustawodawcy podatkowego powinien mieć także determinant drugiego stopnia sposobu sformułowania tej definicji. Chodzi o wyraźne podanie innego znaczenia danego określenia wraz z ustaleniem zakresu jego odniesienia. Warto zauważyć, że chodzi nie tylko o podanie innego znaczenia danego określenia, musi ono również posiadać postać kwalifikowaną, a zatem być wyraźne. Wątpliwości w tym zakresie może budzić definiowanie pojęcia działalności gospodarczej, zarówno w ogólnym, jak i w szczegółowym prawie podatkowym. Analiza tego zagadnienia wykracza jednakże poza ramy niniejszego opracowania. Determinant drugiego stopnia sposobu sformułowania definicji w prawie podatkowym wskazuje na podanie wyraźnie innego znaczenia danego określenia, a zatem nie podnosi się zagadnienia nowości znaczeniowej, charakterystycznego dla determinantów pierwszego stopnia. Nie można jednakże wykluczyć takich sytuacji, gdy z uwagi na podnoszoną relację pomiędzy obrotem gospodarczym a prawem podatkowym również formułowanie definicji w konkretnej ustawie podatkowej będzie motywowane nowością znaczeniową poza odejściem od znaczenia nadanego w ustawie o szczególnym charakterze normatywnym.

\section{Podsumowanie}

Ustawodawca podatkowy — podejmując decyzję o wprowadzeniu definicji legalnej, a także jej sformułowaniu — powinien korzystać z odpowiednich determinantów. Ma to istotny walor wówczas, gdy umieszczając definicję legalną, odwołuje się do nowości znaczeniowej czy też odchodzi od znaczenia danego terminu nadanego w ustawie o szczególnym charakterze normatywnym. Konieczne 
zatem staje się dostrzeganie przez ustawodawcę tych determinantów, które można wskazać już na etapie poprzedzającym podjęcie decyzji o zdefiniowaniu danego terminu, ale także tych, które wskazują sposób jej wyrażenia. Jest to ważne nie tylko dla systemu prawa podatkowego, ale także rodzi konsekwencje dla praktyki podatkowej z uwagi na trudności w ustaleniu zakresu definicji.

Wybór przez ustawodawcę podatkowego obszaru wymagającego definicji, a także sposób jej sformułowania, sprzyja również wyrażeniu właściwej relacji pomiędzy obrotem gospodarczym a prawem podatkowym. Zwłaszcza w tych przypadkach, w których chodzi o powołanie się na nowość znaczeniową czy też odejście od znaczenia nadanego w ustawie mającej wymiar kodeksu, określanej jako prawo lub też mającej podstawowe znaczenie dla danej dziadziny spraw.

\title{
Bibliografia
}

Borszowski P., Określenia nieostre w przepisach dot. przedmiotu opodatkowania podatkiem dochodowym od osób fizycznych (wprowadzenie do problematyki), „BAS” 2018, nr 2.

Borszowski P., Określenia nieostre i klauzule generalne w prawie podatkowym, Warszawa 2017. Borszowski P., Pomiędzy elastycznościa przepisów prawa podatkowego a definicjami legalnymi, [w:] Ksiega jubileuszowa ku czci profesor Krystyny Sawickiej: gromadzenie i wydatkowanie środków publicznych: zagadnienia finansowoprawne, red. W. Miemiec, Wrocław 2017. Mastalski R., Autonomia prawa podatkowego a spójność i zupetność systemu prawa, „Przegląd Podatkowy" 2003, nr 10.

Zieliński M., [w:] S. Wronkowska, M. Zieliński, Komentarz do zasad techniki prawodawczej, Warszawa 2012.

\section{Defining concepts in tax law and establishing a new (different) meaning of the term}

\author{
Summary
}

The article analyzes one of the basic defining concepts in tax law. It is about creating a new meaning of the term. The author indicates that the tax legislator creating such concepts does not use determinants. The article indicates the first and second degree determinants for the creation of these definitions.

Keywords: legal definitions in tax law, determinants of creating legal definitions, new meaning of the term. 